Bulletin of Pharmaceutical Sciences
Assiut University
Website: http://bpsa.journals.ekb.eg/
e-mail: bullpharm@aun.edu.eg

\title{
PLASMA EPSTEIN-BARR VIRUS (EBV) DNA AS A BIOMARKER FOR DIAGNOSIS OF SYRIAN EBV-POSITIVE BURKITT'S LYMPHOMA
}

\author{
Rana Habeeb $^{1 *}$, Lina Al Hafar ${ }^{2}$ and Fawza Monem ${ }^{1,3}$ \\ ${ }^{1}$ Department of Biochemistry and Microbiology, Faculty of Pharmacy, Damascus University, \\ Damascus, Syria \\ ${ }^{2}$ Department of Pathology, Faculty of Medicine, Damascus University, Damascus, Syria \\ ${ }^{3}$ Department of Clinical Laboratories, Al-Assad Hospital, Damascus University, Damascus, \\ Syria
}

\begin{abstract}
Epstein-Barr virus - positive Burkitt's Lymphoma is defined as the presence of EpsteinBarr virus $(E B V)$ in tumor cells, the standard way to detect (EBV) in Burkitt's Lymphoma is insitu hybridization (ISH) of EBV-encoded small RNA (EBERs) in tumor cells. The present study aimed to evaluate plasma Epstein-Barr virus (EBV) DNA as a noninvasive biomarker for diagnosis and prognosis of EBV-positive Burkitt's lymphoma. The study included 40 newly diagnosed patients with Burkitt's lymphoma, ranging in age from 4 to 60 years, and 55 sex and age-matched controls. Forty formalin-fixed paraffin-embedded blocks of Burkitt's lymphoma tissue samples were used to investigate the EBV by in-situ hybridization detection of the EBERs. Plasma EBV DNA was quantified by real-time quantitative polymerase chain reaction (PCR) for all Burkitt lymphoma patients prior to therapy and for control. The results showed that (22/40, $55 \%)$ of Burkitt lymphoma were positive for histological EBER, whereas plasma EBV DNA was detectable (range from $1.2 \times 10^{4}$ to $4.7 \times 10^{6}$ copies $/ \mathrm{mL}$ ) in all EBV-positive Burkitt lymphoma samples (22/22). EBV DNA was undetectable in all cases of EBV-negative Burkitt lymphomas (18/18) and all healthy control (55/55). It is worth mentioning that our results demonstrated that the EBV DNA load was significantly high in the EBV-positive BL patients suffering poor prognostic state. In conclusion: Plasma EBV-DNA can be used as a noninvasive biomarker for diagnosis and prognosis of EBV-positive Burkitt's lymphoma.
\end{abstract}

\section{INTRODUCTION}

Epstein Barr virus (EBV) is associated with a variety of lymphomas/leukemias, and epithelial malignancies, including Burkitt's lymphoma (BL), Hodgkin lymphoma (HL), and nasopharyngeal carcinoma ${ }^{1}$. EBV-associated malignancies are associated with a latent form of infection ${ }^{1}$, where EBV expresses restricted sets of proteins called EBV transcription programs (ETPs) in every tumor cell, including six nuclear antigens (EBNAs), three latent membrane proteins (LMP), and untranslated RNA called EBV- encoded small RNA (EBERs), these latent proteins and EBER can mediate cellular transformation ${ }^{1}$. The presence of EBV in the tumor cells of EBV-associated malignancies might afford a basis for specific therapy $^{2}$. New research concentrate on application of different new treatment strategies targeting the EBV within tumor cells $^{3}$. The diagnosis of EBV-associated malignancies is principally based on biopsy of the primary tumor, where EBER in-situ hybridization is used to determine if there is an association with $\mathrm{EBV}^{1}$. However, it can be difficult to perform a biopsy because of difficulties obtaining a biopsy of the tumor or poor patient status. Many Studies in EBV association tumors including lymphoma have suggested that the EBV-DNA can be detected in the plasma of most patients with EBVassociated malignancies ${ }^{4}$, which is derived from apoptotic or necrotic tumor cells as naked 
DNA fragments ${ }^{5 \& 6}$, while it remains undetectable in non EBV associated tumor or in healthy individuals ${ }^{7}$. Plasma EBV DNA has recently played a more important role in the diagnosis and management of EBV-associated cancers $^{8}$, especially in Hodgkin lymphoma $(\mathrm{HL})^{9 \& 10}$, and nasopharyngeal carcinoma ${ }^{11 \& 12}$, but there is limited data available on the diagnostic and prognostic significance of plasma EBV DNA for Burkitt's lymphoma. The World Health Organization has promoted cooperative studies about plasma EBV DNA quantification across organizations and countries to establish appropriate guidelines for EBV associated tumor diagnosis and treatment ${ }^{4}$.

Burkitt's lymphoma (BL) is an aggressive, non-Hodgkin lymphoma (NHL) ${ }^{13}$. There are three types of Burkitt's lymphoma which differ in geographic distribution and Epstein-Barr virus (EBV) association ${ }^{14}$ : Endemic (eBL), sporadic (sBL), and HIV-associated BL. Endemic BL which is associated with (EBV) in over $95 \%$ of cases, and it is predominant in the malaria endemic regions such as Equatorial Africa and Papua New Guinea ${ }^{13}$, Common sites of tumor occurrence of eBL are the jaws and other facial bones ${ }^{13}$. Sporadic Burkitt's lymphoma (sBL) has a wide global distribution outside Africa, the rate of its association with EBV ranges from 15 to $80 \%$, common sites of tumor occurrence of sBL are intra-abdominal regions $^{14 \& 15}$. EBV-positive $\mathrm{BL}$ is defined as the presence of EBV in tumor cells ${ }^{13}$, the expression of EBV genes in BL restricted to the type I latency default programs, where Only EBNA-1 and EBER are expressed in EBV positive cells in BL tumors ${ }^{13}$. The standard way to detect Epstein-Barr virus (EBV) in Burkitt lymphoma is by in-situ hybridization (ISH) of EBV-encoded small RNA (EBER) in tumor cells $^{16}$. In this study we aimed to evaluate plasma Epstein-Barr virus (EBV) DNA as a noninvasive biomarker for diagnosis and prognosis of EBV-positive Burkitt's lymphoma.

\section{MATERIALS AND METHODS}

\section{Study groups}

This prospective cross-sectional study enrolled forty newly diagnosed Burkitt's lymphoma patients, During the period from
1/9/2017 to 1/1/2019, from Al-Assad University Hospital, Mouwasat University Hospital, and University Children's Hospital in Damascus.

An age- and sex matched control group of 55 healthy volunteers were also included.

All cases (40) of BL were confirmed by morphologic, immunohistochemical, and molecular analyses carried out according to the World Health Organization (WHO) classification criteria for Non-Hodgkin's lymphoma $^{17}$ and were adopted from their medical records. All showed classic type distinguished by a proliferation of mediumsized cells, basophilic cytoplasm, and numerous mitotic figures with a starry-sky pattern Image, they also were characterized by c-MYC translocation and CD20+/CD10+/bcl2-/bcl-6+/CD3- with a very high Ki-67 proliferation index.

We obtained patients' clinical data from their medical records, which included gender, age, and tumor localization. All patients underwent a staging assessment according to the Murphy/St. Jude's staging system for nonHodgkin $^{18}$. None of the patients had primary or acquired immunodeficiencies. BL patients were treated according to BFM-NHL protocol ${ }^{19}$. Medical records were reviewed for treatment response and clinical state within 20 months through a physical exam, chest x-ray, and computed tomography of the chest and abdomen.

All patients and control were informed consent after the approval of the ethical committee in Damascus University.

\section{Sampling}

Formalin-fixed paraffin embedded blocks of Burkitt's lymphoma tissue samples were used to investigate the presence of EBV by detecting EBERs using in-situ hybridization method.

Peripheral venous blood $(5 \mathrm{~mL})$ samples were taken from patients and controls into EDTA -treated tubes, and centrifuged at $1200 \mathrm{~g}$ for $10 \mathrm{~min}$. Plasma isolation was performed immediately and freezed at $-80^{\circ} \mathrm{C}$ until assay. DNA was extracted from $300 \mu \mathrm{L}$ of plasma using a QIAamp DNA Blood Minikit (Qiagen, Germany) and eluted in $100 \mu \mathrm{L}$ AE buffer (Qiagen, Germany), according to manufacturer instructions. 
EBV investigation

In-situ hybridization for Epstein-Barr virusencoded RNA

The presence of EBV was detected by in situ hybridization for EBV-encoded RNA (EBER) by histopathologic examination of the neoplastic cells by using a Biotin-labeled ZytoFast CISH probe, Zyto Fast CISH Implementation Kit AP-NBT/BCIP (Zytovision, Germany), according to manufacturer instructions.

\section{Plasma EBV DNA quantification}

Plasma EBV DNA were evaluated in controls and in naive BL patients by a real-time quantitative polymerase chain reaction (qPCR) assay, by using artus EBV LC PCR Kit (QIAGEN, Germany) on LightCycler 2.0 instrument (Roch, Germany).

The EBV LC PCR Master reagent kit contained Primers and enzymes for the specific amplification of a $97 \mathrm{bp}$ region of the EBNA1 gene of the EBV genome. Quantification standards were provided with the kit, and were included in each run to generate the standard curve for EBV load determination.

\section{Statistical analysis}

Chi-square test/Fisher exact test was applied to compare variables between patient groups. Mann-Whitney- test and KruskalWallis test were also used. A receiver operating characteristic curve was used to determine the cutoff value for plasma EBV-DNA with optimal sensitivity, specificity, and concordance with tumor EBV status by EBERISH. SPSS Statistics version 25 was used for statistical analysis. P-value $<0.05$ was considered statistically significant.

\section{RESULTS AND DISCUSSION}

\section{Results}

Of the $40 \mathrm{BL}$ cases, 29 (72.5\%) were males and $11(27.5 \%)$ were females. there was a male predominance in sex distribution $(\mathrm{M}: \mathrm{F}$ $=2.6: 1$ ). Patients ranged in age from 4 to 60 years, distributed in two age groups: pediatric group (4-12 Y, average $8 \mathrm{Y}$ ) $(37 / 40,92.5 \%)$, and adult group (48-60 Y, average $54 \mathrm{Y})(3 / 40$, $7.5 \%$ ). In all Burkitt lymphoma patients, the tumor was located in the abdomen.
EBV was detected in tumor cells by ISH, the results showed that $(22 / 40,55 \%)$ of paraffin-embedded formalin-fixed tumor specimens were positive for EBER (Fig. 1a), while $(18 / 40,45 \%)$ were negative for EBER (Fig. 1b).
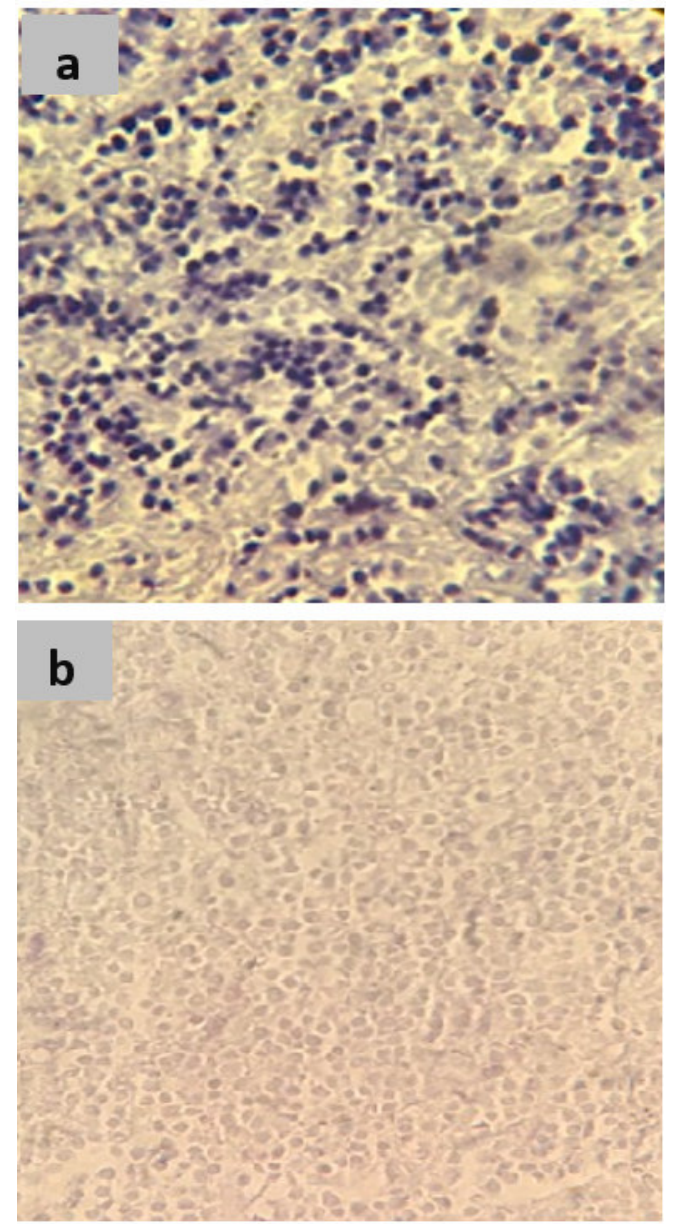

Fig. 1: EBER in situ hybridization: (a) A Case of EBV positive Burkitt lymphoma showing a dark blue-violet positive staining in the nucleus of neoplastic cells $(\times 400)$; (b) A Case of EBV negative Burkitt lymphoma where no dark blue-violet color appears in the nucleus of tumor cells indicating negative EBER $(\times 400)$.

Plasma EBV DNA levels ranging from $1.2 \times 10^{4}$ to $4.7 \times 10^{6}$ copies $/ \mathrm{mL}$ (median: $8.3 \times 10^{5}$ copies $/ \mathrm{mL}$ ) were detected in all cases of EBV-positive BL patients (22/22), meanwhile the EBV DNA was not detected in the plasma of patients who had EBV-negative tumors (18/18). 
Our results demonstrated that data obtained from both histopathological and serological detection methods of EBV completely coincided $(100 \%)$. A cutoff for plasma EBV-DNA >12000 viral copies/mL yielded 100\% concordance with EBER-ISH. On the other hand, the EBV in samples (55/55) of healthy individuals was undetectable.

Our samples (40) were distributed according to medical records into (24/40, $16 / 40$ ) patients in advanced stage and in limited stage respectively. All plasma EBV DNA and EBER positive cases (22/22) were in advanced stage, distributed between stage III and stage IV (18/22, 4/22), respectively. Albeit (16/18) of plasma EBV DNA and EBER negative cases were in limited stage (stage II), $(2 / 18)$ were in advanced stage (stage III). This give an evidence of significant correlation between EBV presence in BL and advanced stage ( $p=$ 0.001).

Treatment responses were evaluated according to international response criteria for lymphoma $^{20}$, we assessed all the cases over 20 months after the beginning of treatment. We found that all diagnosed $\mathrm{EBV}$-negative $\mathrm{BL}$ who were plasma EBV DNA negative had responded to treatment with complete remission $(18 / 18,100 \%)$. Conversely, the outcomes were worse for EBV-positive BL, whereas $(14 / 22,63.6 \%)$ patients had died, $(3 / 22, \quad 13.7 \%)$ patients had Refractory lymphoma (resistant to treatment), $(2 / 22,9 \%)$ patients had relapsed lymphoma, and (3/22, $13.7 \%$ ) patients had responded to treatment with complete remission.

The median concentration of pretreatment plasma DNA EBV was significantly higher in later deceased patients $\left(3.9 \times 10^{6}\right.$ copies $/ \mathrm{mL}, p=$ 0.047 ) as compared with patients with relapse lymphoma $\left(4.9 \times 10^{5}\right.$ copies $\left./ \mathrm{mL}\right)$, patients with Refractory lymphoma $\left(4.3 \times 10^{5}\right.$ copies $\left./ \mathrm{mL}\right)$, and patients who had responded to treatment with complete remission, whose level values were significantly low $\left(7.1 \times 10^{4}\right.$ copies $\left./ \mathrm{mL}\right)$. No significant difference was observed between the plasma EBV DNA levels in patients with relapsed lymphoma $\left(4.9 \times 10^{5}\right.$ copies $/ \mathrm{mL}$ ) and with patients with Refractory lymphoma $\left(4.3 \times 10^{5}\right.$ copies $\left./ \mathrm{mL}, p=0.09\right)$.

Table 1 demonstrates the distribution of EBV positive BL and EBV negative BL according to clinical stages and treatment responses evaluation over 20 months as well as the Median plasma EBV DNA for each group.

Table 1: Distribution of EBV positive BL and EBV negative BL according to clinical stages, and Treatment responses evaluation over 20 months, besides the median plasma EBV DNA for each group.

\begin{tabular}{||c|c|c|c|c||}
\hline \multirow{2}{*}{} & \multicolumn{2}{|c|}{$\begin{array}{c}\text { EBV positive Burkitt lymphoma } \\
(n=22)\end{array}$} & \multicolumn{2}{|c|}{$\begin{array}{c}\text { EBV negative Burkitt lymphoma } \\
(n=18)\end{array}$} \\
\cline { 2 - 5 } & $\begin{array}{c}\text { EBER -ISH* } \\
\text { positive } \\
(\mathrm{n})\end{array}$ & $\begin{array}{c}\text { Median plasma } \\
\text { EBV DNA } \\
\text { Copies/ml }\end{array}$ & $\begin{array}{c}\text { EBER-ISH* } \\
\text { negative } \\
(\mathrm{n})\end{array}$ & $\begin{array}{c}\text { Median plasma } \\
\text { EBV DNA } \\
\text { Copies/ml }\end{array}$ \\
\hline Clinical stage & & & $2 / 18(11 \%)$ & undetectable \\
\hline Advanced stage & $22 / 22(100 \%)$ & $8.3 \times 10^{5}$ & $16 / 18(89 \%)$ & undetectable \\
\hline Limited stage & $0 / 22(0 \%)$ & & $0 / 18(0 \%)$ & \\
\hline Treatment responses evaluation (over 20 months) & $0 / 18(0 \%)$ & \\
\hline Patients had died & $14 / 22(63.6 \%)$ & $3.9 \times 10^{6}$ & $0 / 18(0 \%)$ & \\
\hline $\begin{array}{c}\text { Patients had Refractory } \\
\text { lymphoma }\end{array}$ & $3 / 22(13.7 \%)$ & $4.3 \times 10^{5}$ & $4.9 \times 10^{5}$ & undetectable \\
\hline $\begin{array}{c}\text { Patients had relapsed } \\
\text { lymphoma }\end{array}$ & $2 / 22(9 \%)$ & $7.1 \times 10^{4}$ & $22 / 22(100 \%)$ & \\
\hline $\begin{array}{c}\text { Patients had responded } \\
\text { to treatment }\end{array}$ & $3 / 22(13.7 \%)$ & &
\end{tabular}

EBER-ISH*: EBV-encoded small RNA (EBER) in-situ hybridization

Plasma EBV DNA $\dagger$ : plasma Epstein-Barr Virus DNA 


\section{Discussion}

In our study, the incidence of Burkitt's lymphoma was higher in children $(92.5 \%)$ as compared with adults, this corresponds to many studies which report that Burkitt's lymphoma is more common in children ${ }^{21 \& 22}$. The exact cause of the high incidence of Burkitt's lymphoma in children is not known yet. We believe that exposure to EBV infections in childhood may increase a child's risk of having Burkitt lymphoma.

Our data showed that $\mathrm{BL}$ incidence among males is significantly higher than in females, and this compatible with many studies which report that Burkitt's lymphoma is more prevalent in males compared to females ${ }^{22-25}$.

In concordance with other studies ${ }^{26}$, we observed a lower incidence of Burkitt lymphoma between females. We agree with Yakimchuk et al. point of view that estrogen has anti-proliferative effect on Burkitt lymphoma cells through estrogen receptor $\beta$ $(\mathrm{ER} \beta)$ signaling $^{26}$.

Our study is the first study about association of EBV with Burkitt lymphoma in Syria, with respect to the incidence rate of EBV-positive Burkitt lymphoma in our cases $(22 / 40,55 \%)$, it was higher than is reported in developed countries $(15-30 \%)^{24}$, and intermediate between those of Asian countries $(50 \%, 80 \%, 30.5 \%)$ in Iran, Iraq and China respectively ${ }^{23,24 \& 27}$, and those of Latin American countries $(52 \%, 37 \%)$ in Brazil and Argentina respectively ${ }^{28 \& 29}$. The rate obtained in our study might be due to childhood primary infection of EBV usually occurs in these countries in childhood, and this inappropriate socioeconomic level which may lead to immune impairment and lack of monitoring and control of latent infection with $\mathrm{EBV}^{30 \& 31}$.

Our results demonstrated that the presence of EBV DNA in plasma reflects the presence of EBV in tumor cells, with perfect compatibility $(100 \%)$ when performed by histological detection method (ISH) and serological detection methods (PCR). Similarly, we found compatibility of undetectable plasma EBV DNA levels and EBER-ISH negative cases of BL and healthy control. Our findings agree with those of Westmoreland et al., Machado et $a l$. and Kabyemera et al. ${ }^{16,7 \& 32}$. This perfect compatibility gave evidence to consider EBV DNA in plasma as a noninvasive biomarker for diagnosing EBV-positive Burkitt lymphoma.

Our results indicated that all plasma EBV DNA and EBER positive Burkitt samples were obtained from patients in an advanced stage $(22 / 22)$, with a high death rate $(63 \%)$ and a low response rate to treatment (13\%). In contrast, most of the plasma EBV DNA and EBER negative Burkitt samples of those who were in limited-stage (16/18) with a high response rate to treatment $(100 \%)$, these results indicated a poor prognostic value for EBV presence in Burkitt lymphoma. We agree to the opinion which explains that is due to the role of EBNA and EBERs in apoptosis inhibition and increasing the rate of neoplastic cell proliferation $^{30}$. Previous studies have demonstrated that EBERs induce interleukin10 , an autocrine growth factor for Burkitt's lymphoma cells, by activating RIG-I/interferon regulatory factor 3 pathway ${ }^{33}$. EBERs were also found to bind retinoic acid-inducible gene I (RIG-I) and thus activate its downstream signaling $^{33}$. EBNA is essential for viral DNA replication and episome maintenance during cellular replication at latent stages ${ }^{34}$, EBNA1 also contribute to the oncogenic process by upregulating the apoptosis suppressor protein, survivin in EBV-associated B-lymphoma cells $^{35}$, so EBNA1 is associated with the survival of Burkitt's lymphoma cells ${ }^{34 \& 35}$.

Although Westmoreland D et al. ${ }^{16}$, and Wang et al. ${ }^{36}$ finding is similar to ours, but there are few studies on the prognostic value of EBV in Burkitt lymphoma due to high mortality rate, delay in diagnosis, and rapid tumor spread and proliferation.

Our results demonstrated that outcomes for EBV positive Burkitt's patients were worse in patients who had elevated plasma EBV DNA, where the highest values of plasma DNA EBV were for later deceased patients, then in patients who had relapsed lymphoma or patients with Refractory lymphoma. And on the contrary, the lowest values were in patients who had responded to treatment with complete remission. Hence plasma EBV DNA may be used as prognostic marker. Our result was compatible with the result obtained by Westmoreland et al. ${ }^{16}$, and Kabyemera ${ }^{32}$. As 
well the quantification of plasma DNA EBV loads has played an important role in the diagnosis and management of other EBVassociated malignancies. Viral load measurement is particularly useful for assessing the prognosis or response to therapy of EBV-associated intractable lymphomas like extranodal NK/T-cell lymphoma ${ }^{37 \& 38}$, posttransplant lymphoproliferative disorder ${ }^{39}$, nasopharyngeal carcinoma (NPC) ${ }^{40}$, and EBVpositive gastric carcinoma ${ }^{41}$. Kanakry JA study showed That EBV-DNA in plasma is highly correlated with EBV tumor status in HL and is significant for determining the prognosis before therapy and at follow-up after 6 months ${ }^{42}$.

We believe that the diagnostic and prognostic value of plasma EBV DNA in EBV positive $\mathrm{BL}$ is due to the fact that most EBVtumor cells in EBV positive Burkitt lymphoma persist in tumor tissues ${ }^{13}$, and the plasma EBVDNA is resulting from apoptotic or necrotic tumor cells which pass into the peripheral blood $^{43}$. Although it was estimated that $95 \%$ of the population in the world have an asymptomatic lifelong EBV infection ${ }^{44}$, less than $5 \%$ have detectable levels of EBV DNA in plasma $^{44}$. The virus remains latent in the B lymphocyte pool with little cell turnover ${ }^{44}$, that the tenny amounts of EBV DNA in healthy people, if any, released from cell death or viral reactivation would not be sufficient to be detected in the circulation ${ }^{43}$. In contrast, there is a much higher cell turnover rate in cancers, e.g., up to 200000 cancer cells/day in $\mathrm{NPC}^{40}$, which would release sufficient cell-free EBV DNA into the circulation to be detected. Moreover, Ryan JL study showed that in patients with EBV-related malignancies, very few of the EBV-DNA in plasma is encapsidated $^{45}$, suggesting that cell-free EBVDNA is derived from apoptotic or necrotic EBV-infected cells in tumors ${ }^{45}$. Accordingly, the release of EBV DNA into the circulation is in turn determined by the cancer cell population ${ }^{43}$. As that, plasma EBV-DNA can reflect a patient's tumor burden and the cell damage caused by inflammation or immunity ${ }^{43}$. Hence, plasma EBV DNA constitutes a suitable candidate as a biomarker for evaluating tumor severity and prognosis of EBV positive BL patients.

\section{Conclusions}

We recommend plasma EBV-DNA testing in naïve $\mathrm{BL}$ patients for diagnosis EBVpositive BL and predicting prognosis. The main limitation is the small number of cases. Further studies are needed to evaluate the use of plasma EBV-DNA as a biomarker for monitoring response to treatment in patients with EBV-positive BL.

\section{REFERENCES}

1- R. Ayee, M. Ofori, E. Wright and O. Quaye, "Epstein Barr virus associated lymphomas and epithelia cancers in humans", Journal of Cancer, 11 (7), 1737-1750 (2020).

2- R. Gala, J. Gandhi, G. Gupta, S. Grover, A. Sharma, et al., "Study of association of Epstein-Barr virus in lymphomas by Epstein-Barr virus-encoded RNA in situ hybridization: An Indian perspective from a tertiary care cancer institute", Indian Journal of Pathology and Microbiology, 60, 341-349 (2017).

3- K. Hui, A. Cheung, C. Choi, P. Yeung, J. Middeldorp, et al., "Inhibition of class I histone deacetylases by romidepsin potently induces Epstein-Barr virus lytic cycle and mediates enhanced cell death with ganciclovir", International Journal of Cancer, 138, 125-136 (2016).

4- H. Kimura and Y. Kwong, "EBV viral loads in diagnosis, monitoring, and response assessment", Frontiers in Oncology, 9, 1-25 (2019).

5- J. Welch, C. Schwartz, M. Higman, L. Chen, A. Buxton, J. Kanakry, S. Kahwash, et al., "Epstein-Barr virus DNA in serum as an early prognostic marker in children and adolescents with Hodgkin lymphoma", Blood Advances, 1, 681-684 (2017).

6- J. L. Ryan, H. Fan, L. J. Swinnen, S. A. Schichman, N. Raab-Traub, et al., "Epstein-Barr virus (EBV) DNA in plasma is not encapsulated in patients with EBV- 
related malignancies", Diagn. Mol. Pathol., 13, 61-68 (2004).

7- A. Machado, M. Robaina, M. Rezende and A. Klum, "Circulating cell-free and Epstein-Barr virus DNA in pediatric Bnon-Hodgkin lymphomas", Leukemia \& Lymphoma, 51, 1020-1027 (2010).

8- J. Kanakry and R. Ambinder, "The biology and clinical utility of EBV monitoring in blood", Curr. Top. Microbiol. Immunol., 391, 475-499 (2015).

9- B. Kanapuru, "Plasma EBV levels as a prognostic marker in patients with advanced Hodgkin lymphoma", Clinical Oncology, 34, 234-239 (2013).

10- M. Sinha, C. Rama Rao, M. Shafiulla, B. Shankaranand, et al., "Plasma Epstein Barr viral load in adult-onset Hodgkin lymphoma in South India", Hematol. Oncol. Stem. Cell Ther., 9, 8-13 (2015).

11- Y. Sherwood, W. K. Jacky and C. Kwan, "Clinical utility of circulating EpsteinBarr virus DNA analysis for the management of nasopharyngeal carcinoma", Chinese Clinical Oncology, 5, 112-125 (2016).

12- S. J. Chai, K. C. Pua, A. Saleh, et al., "Clinical significance of plasma EpsteinBarr virus DNA loads in a large cohort of Malaysian patients with nasopharyngeal carcinoma", J. Clin. Virol., 5534-39 (2012).

13- M. Rowe, L. Fitzsimmons and A. Bell, "Epstein-Barr virus and Burkitt lymphoma", Chin. J. Cancer, 33, 609-619 (2014).

14- E. Queiroga, G. Gualco, L. M. Weiss, D. P. Dittmer, I. Araujo, et al., "Burkitt lymphoma in Brazil is characterized by geographically distinct clinicopathologic features", Am. J. Clin. Pathol., 130, 946956 (2008).

15- K. Kalisz, F. Alessandrino, R. Beck, D. Smith, E. Kikano, N. Ramaiya and S. Tirumani "An update on Burkitt lymphoma: A review of pathogenesis and multimodality imaging assessment of disease presentation, treatment response, and recurrence", Insights into Imaging, 10, 1-29 (2019).
16- K. D. Westmoreland, N. D. Montgomery, C. C. Stanley, et al., "Plasma Epstein-Barr virus DNA for pediatric Burkitt lymphoma diagnosis, prognosis and response assessment in Malawi", Int. J. Cancer, 140, 2509-2516 (2017).

17- S. H. Swerdlow, E. Campo, N. L. Harris, et al., "WHO Classification of Tumors of Haematopoietic and Lymphoid Tissues", Vol. 2, $4^{\text {th }}$ Edn., Lyon, International Agency for Research on Cancer (2008).

18- S. M. Feinberg, S. Ignatius, G. U. Mai and T. Shibuya, "Burkitt's lymphoma of the base of the tongue: A case report and review of the literature", Ear, Nose, \& Throat Journal, 8, 356-360 (2007).

19- S. Smeland, A. K. Blystad, S. O. Kvaløy, M. Ikonomou, J. Delabie and G. Kvalheim, "Treatment of Burkitt's/ Burkitt-like lymphoma in adolescents and adults: a 20-year experience from the Norwegian Radium Hospital with the use of three successive regimens", Annals of Oncology, 15, 1072-1078 (2004).

20- D. Cheson, B. Pfistner, M. Juweid, R. Gascoyne, L. Specht, et al., "Revised response criteria for malignant lymphoma", Journal of Clinical Oncology, 25, 579-583 (2007).

21- C. F. Bi, Y. Tang, W. Y. Zhang, S. Zhao, X. Q. Wang, Q. P. Yang, et al., "Sporadic Burkitt lymphomas of children and adolescents in Chinese: A clinicopathological study of 43 cases", Diagn. Pathol., 7, 22 (2007).

22- H. Huang, Z. Liu, H. Zeng, S. Zhang, C. Huang, et al., "Clinicopathological study of sporadic Burkitt lymphoma in children", Chinese Medical Journal, 128, 510-515 (2015).

23- S. Uccini, M. Al-Jadiry, S. Scarpino, A. Al-Hadad, et al., "Burkitt lymphoma in Iraqi children: A distinctive form of sporadic disease with high incidence of $\mathrm{EBV}+$ cases andmore frequent expression of MUM1/IRF4 protein in cases with head and neck presentation Stefania", Pediatr. Blood Cancer, 65, 272-299 (2018).

24- P. Deyhimi and M. Kalantari, "Study of Epstein-Barr virus expression in Burkitt's lymphoma by polymerase chain reaction 
and in situ hybridization: A study in Iran", Dental Research Journal, 3, 2350-2370 (2014).

25- M. Pizza, P. Bruniera, S. Luporini, H. Marcelino, et al., "Detection of EpsteinBarr virus in children and adolescents with Burkitt's lymphoma by in situ hybridization using tissue microarrays", Hematology, 13, 2350-2370 (2008).

26- K. Yakimchuk, M. Iravani, M. Hasni, P. Rhönnstad, S. Nilsson, M. Jondal and S. Okret, "Effect of ligand-activated estrogen receptor $\beta$ on lymphoma growth in-vitro and in-vivo", Leukemia, 25, 1103-1110 (2011).

27- C. Qin, Y. Huang, H. Rao, et al., "Clinicopathological features and EBV infection status of lymphoma in children and adolescents in South China: A retrospective study of 662 cases", Diagnostic Pathology, 13, 1-21 (2018).

28- E. M. Queiroga, G. Gualco, et al., "Burkitt lymphoma in brazil is characterized by geographically distinct clinicopathologic features", Am. J. Clin. Pathol., 130, 946956 (2008).

29- L. Julia, C. Melina, M. Elena, A. Luis and P. Maria and C. Paola, "Epstein Barr virus (EBV) association and latency profile in pediatric Burkitt's lymphoma: Experience of a single institution in Argentina", Journal of Medical Virology, 86 (5), 845 850 (2014).

30- S. Gromminger, J. Mautner, G. Bornkamm and M. Al Jadiry, "Burkitt lymphoma: The role of Epstein-Barr virus revisited", British Journal of Hematology, 156, 719 729 (2012).

31- W. P. Yang, H. Huang, L. P. Gong, Y. Wu, H. Y. Xu, Y. Zou, et al., "Molecular genetic features of sporadic Burkitt's lymphoma in children (in Chinese)", Chin. J. Pathol., 39, 819-24 (2010).

32- R. Kabyemera, N. Masalu, P. Rambau, E. Kamugisha, B. Kidenya, A. Rossi, et al., "Relationship between Non-Hodgkin's lymphoma and blood levels of EpsteinBarr Virus in children in north-western Tanzania: A case control study", $\boldsymbol{B} \boldsymbol{M C}$ Pediatrics, 13, 44-55 (2013).
33- D. Iwakiri, "Epstein-Barr virus-encoded RNAs: Key molecules in viral pathogenesis", Cancers, 6, 1615-1630 (2014).

34- A. Sharkawy, L. Al-Zaidan and A. M. Malki, "Epstein-Barr virus-associated malignancies: Roles of viral oncoproteins in carcinogenesis", Front. Oncol., 2, 154166 (2018).

35- J. Lua, M. Murakamia, C. Subhash and S. Erle, "Epstein-Barr virus nuclear antigen 1 (EBNA1) confers resistance to apoptosis in EBV positive B-lymphoma cells through up-regulation of surviving", Virology, 5, 64-75 (2011).

36- B. J. Wang, X. N. Cen, H. Y. Ren, W. Liu, Z. Y. Liang, Z. X. Qiu, J. P. Ou, W. S. Wang, Y. Li, Y. J. Dong, M. J. Wang, L. H. Wang and Q. Wang, "Epstein-Barr virus status and its prognostic value in lymphoma", Ann. Hematol. Oncol., 3 (5), Article ID 1094, 1-6 (2016).

37- J. Cho, S. J. Kim, S. Park, K. H. Yoo, C. S. Ki, Y. Ko, et al., "Significance of circulating Epstein-Barr virus DNA monitoring after remission in patients with extranodal natural killer $\mathrm{T}$ cell lymphoma", Ann. Hematol., 97, 14271436 (2018).

38- J. Y. Ha, H. Sung, A. Jung, Y. S. Lee, et al., "Superiority of Epstein-Barr virus (EBV) DNA in the plasma over whole blood in prognostication of extranodal NK/T cell lymphoma, nasal type (ENKTL)", Blood, 134 (1), 28-46 (2019).

39- M. L. Gulley and W. Tang, "Using Epstein-Barr viral load assays to diagnose, monitor and prevent posttransplant lymphoproliferative disorder", Clinical Microbiology Reviews, 4, 350-366 (2010).

40- C. Kca, W. Jks, A. King, et al., "Analysis of plasma Epstein-Barr virus DNA to screen for nasopharyngeal cancer", $\boldsymbol{N}$. Engl. J. Med., 377, 513-522 (2017).

41- L. Ryan, R. Morgan, R. L. Dominguez, B. Thorne, H. Sandra and M. Kenudson, "High levels of Epstein- Barr virus DNA in latently infected gastric adenocarcinoma", Laboratory Investigation, 19,123-142 (2009). 
42- J. A. Kanakry, H. Li, L. L. Gellert, M. V. Lemas, W. S. Hsieh, F. Hong, et al., "Plasma Epstein-Barr virus DNA predicts outcome in advanced Hodgkin lymphoma: correlative analysis from a large North American cooperative group trial", Blood, 121, 3547-3553 (2012).

43- L. Wai, C. Kwan and Yuk D. "Plasma Epstein-Barr virus DNA as an archetypal circulating tumor DNA marker", $\boldsymbol{J}$. Pathol., 247 (5), 641-649 (2019).
44- L. S. Young, L. F. Yap and P. G. Murray, "Epstein-Barr virus: more than 50 years old and still providing surprises", Nat. Rev. Cancer, 16, 789-802 (2016).

45- J. L. Ryan, H. Fan, L. J. Swinnen, S. A. Schichman, N. Raab-Traub, M. Covington, et al., "Epstein-Barr virus (EBV) DNA in plasma is not encapsidated in patients with EBV-related malignancies", Diagn. Mol. Pathol., 13 (2), 61-68 (2004). 


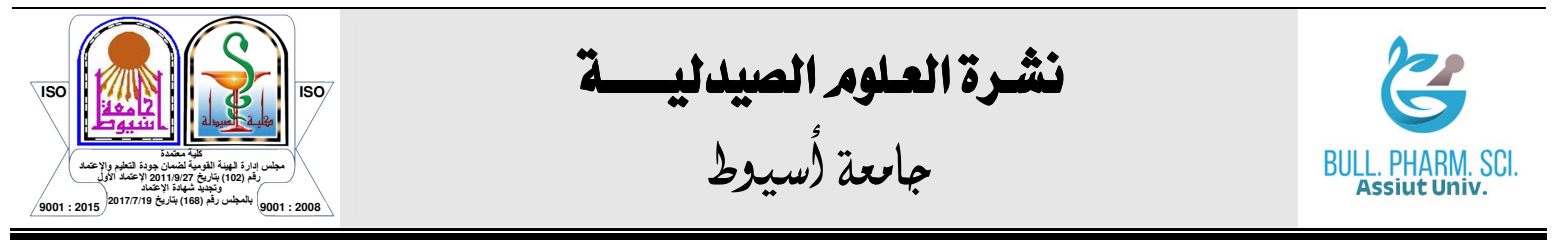

\section{الحض النووي لفيروس إبشتاين بار (EBV) كمؤشر بيولوجي لتشخيص لمفومة} بيركيت إيجابية EBV في سونيار

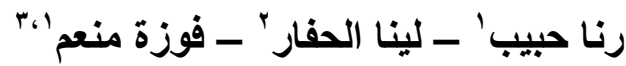

'قسم الكيمياء الحيوية والأحياء الدقيقة ، كلية الصيدلة ، جامعة دمشق ، دمشق ، سوريا

'َقسم الباثولوجيا ، كلية الطب ، جامعة دمشق ، دمشق ، سوريا

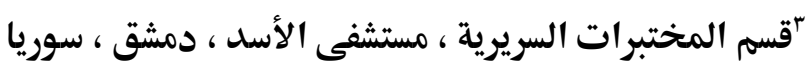

تتميز لمفومة بيركيت إيجابية فيروس إبشتاين بار بوجود فيروس إبشتاين بار (EBV) في جميع

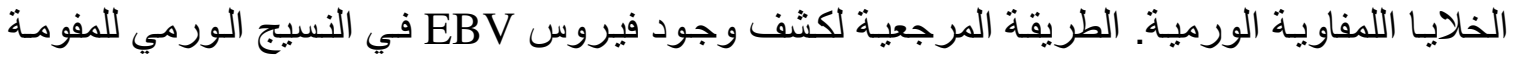

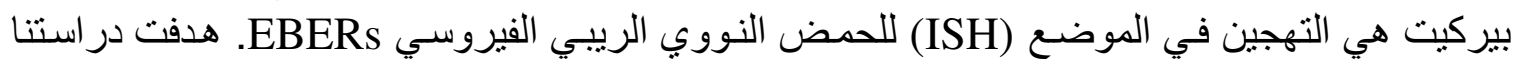
الحالية إلى تقييم الحمض النووي لفيروس إبشتاين بـار EBV DNA الحر في البلازمـا كو اصم حيوي

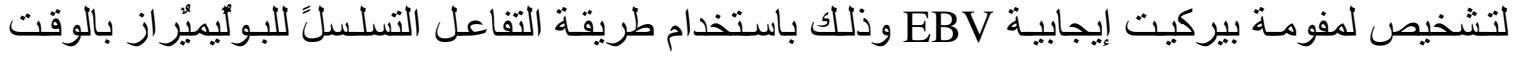
الحقيقي (PCR) و هي طريقة غير باضعة.

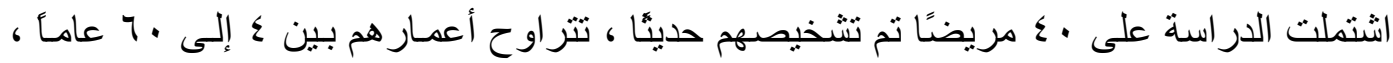

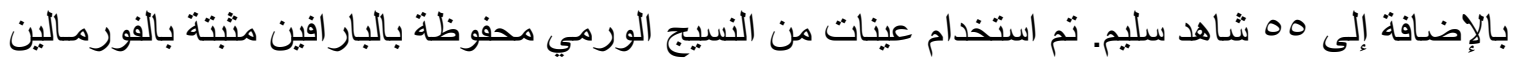

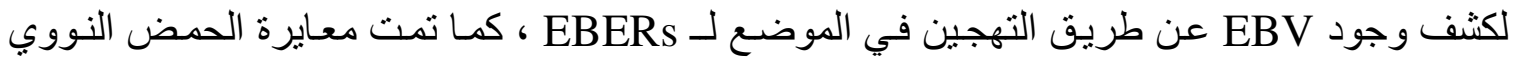

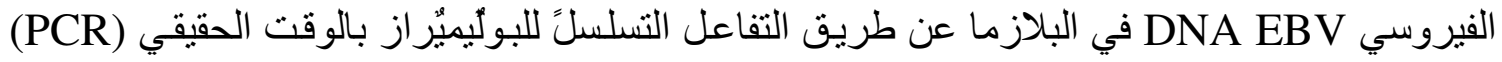
لجميع مرضى لمفومة بيركيت قبل العلاج.

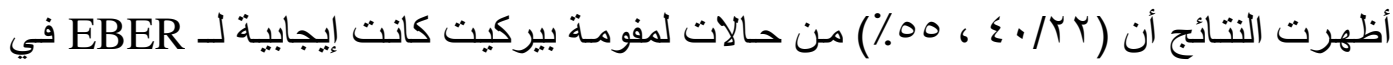

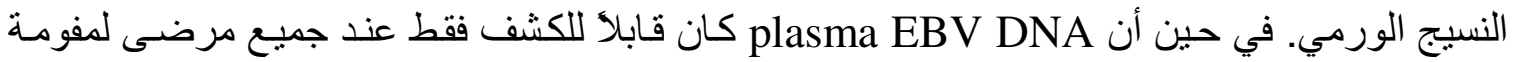

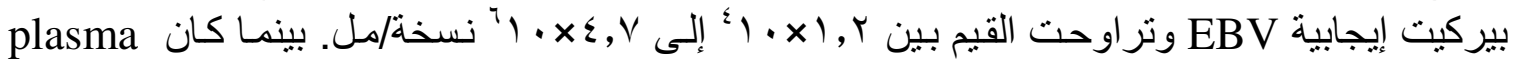

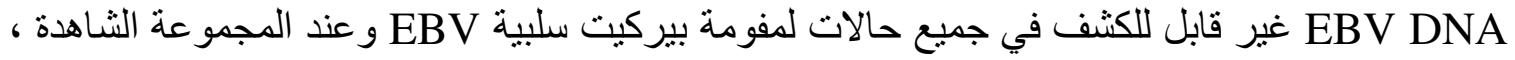

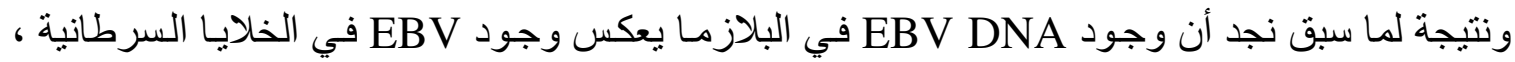

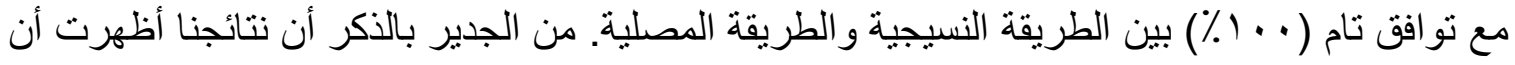
حمل الحمض النووي معB DBNA كان مرتفعًا بشكل ملحوظ عند مرضسى لمفومـة بيركيت إيجابيين

EBV

الخلاصة: يمكن استخدام EBV-DNA كو اصم حيوي غير باضـع لتشخيص لمفومسة بيركيت

إيجابية EBV. 